not a useless petal in the floral egg, not an unneeded line of chasing in the decorated shell. It is shaped beautifully because its shape is needed. In short, it is Nature's method; the identification of beauty and use. But to resume. We may at this point continue our illustrations of the analytical power of moderate lenses by a beautiful instance. We are indebted to Albert Michael of the Linnean Society of England for a masterly treatise on a group of Acari, or Mites, known as the Oribatide. Many of these he has discovered. The one before you is a full grown Nymph, of what is known as a palmicinctum. It is dceply interesting as a form; but for us its interest is that it is minute, being only a millimetre in length. But it repeatedly casts the dorsal skin of the abdomen. Each skin is bordered by a row of exquisite scales; and then successive rows of these scales persist, forming a protection to the entire organism. Mark then that we not only reveal the general form of the Nymph, but the lens reveals the true structure of the scales, not enlargement merely, but detail. The egg of the organism, still more magnified, is also seen.

To vary our examples and still progress. We all know the appearance and structure of chalk. The minute Foraminifera have, by their accumulated tests, mainly built up its enormous masses. But there is another chalk known as Barbadoes earth ; it is siliceous, and is ultimately composed of minute and beautiful skeletons such as those which, enormously magnified, you now see. These were the glassy envelopes which protected the living speck that dwelt within and built it. They are the minutest of the Radiolaria, which pcopled in inconceivable multitudes the Tertiary oceans; and, as they died, their minute skeletons fell down in a continuous rain upon the ocean bed, and became cemented into solid rock, which geologic action has brought to the surface in Barbadoes, and many other parts of the earth. If a piece of this earth, the size of a bean, be boiled in dilute acid and washed, it will fall into powder, the ultimate grains of which are such forms as these which you see. The one bcfore you is an instance of exquisite refinement of detail. The form from which the drawing of the magnified image was made was extremcly small-a mere white speck in the strongest light upon a black ground. But you observe it is not a speck of form merely enlarged. It is not merely beauty of outline made bigger. But there is-as in the delicate group you now see-a perfect opening up of otherwise absolutely invisible details. We may strengthen this evidence in favour of the analytical power of our higher lenses, by one more familiar example, and then advance to the most striking illustration of this power which our most perfect and powerful lenses can afford. I fear that it may be taking too much for granted to assume that every one in an audience like this has seen a human flea ! Most, however, will have a dim recollection or suggestive instinct as to its size in nature. Nothing striking is revealed by this amount of magnification cxcepting the existence of breathing pores, or spiracles along the scale armour of its body. But there is a trace of structure in the terminal ring of the exoskcleton which we cannot clearly define, and of which we may desire to know more. This can be done only by the use of far higher powers.

To effect this, we must carefully cut off this delicate structure, and so prepare it that we may employ upon it the first of a series of our highest powers. The result of that examination is given here. ${ }^{1}$ You see that the whole organ has a distinct form and border, and that its carefully carved surface gives origin to wheel-like areole which form the bases of delicate hairs. The function of this organ is really unknown. It is known from its position as the pygidium; and from the extreme sensitiveness of the hairs to the slightest aërial movement may be a tactile organ warning of the approach of enemies, the eycs have no power to see. But we have not yct reached the ultimate accessible structure of this organ. If we place a portion of the surface under one of the finest of our most powerful lenses, this will be the result. ${ }^{2}$ Now, without discussing the real optical or anatomical value of this result as it stands, what I desire to remind you of is (x) the natural size of the flea ; (2) the increase of knowlcdge gained by its general cnlargement; (3) the relation in size between the flca and its pygidium; and (4) the manner in which our lenses reveal its structure, not merely amplify its form. Now with these simple and yet needful preliminaries you will be able to follow me in a careful study of the least, the very lowliest

I The pygidium of the flea, very highly magnified, was here shown. ${ }^{2}$ An illustration of the pygidium structure seen with $\mathrm{I} / 35$ th immersion
was given and smallest, of all living things. It lies on the very verge of our present powers of optical aid, and what we know concerning it will convince you that we are prepared with competent skill to attack the problem of the life-histories of the smallest living forms. The group to which the subject of our present study belongs is the Bacteria. They are primarily staff-like organisms of extreme minuteness, but may be straight, or bent, or curved, or spiral, or twisted rods. This entire projection is drawn on glass, with camera lucida, each object being magnified 2000 diams., that is to say, four millions of times in area. Yet the entire drawing is made upon an area of not quite three inches in diameter and afterwards projected here. The objects therefore are all equally magnified, and their relative sizes may be seen. The giant of the series is known as Spirillum volutans; and you will see that the representative species given become less and le.s in size until we reach the smallest of all the definite forms and known to science as Bacterium termo.

Now within given limits this organism varies in size, but if a fair average be taken its size is such that 50,000,000 laid in order would only fill the one-hundredth of a cubic inch. Now the majority of these forms move with rapidity and grace in the fluids they inhabit. But how? by what means? By looking at the largest form of this group you will see that it is provided with two delicate fibres, one at each end. Ehrenberg and others strongly suspected their existence, and we were enabled, with more perfect lenses, to demonstrate their presence some twelve years ago. They are actually the swimming organs of this Spirillum. The fluid is lashed rhythmically by these fibres, and a spiral movement of the utmost grace results. Then do the intermediate forms that move also possess these flagella? and does this least form in nature, viz. Bacterium termo, accomplish its bounding and rebounding movements in the same way? Yes! by a series of resolute efforts, in using a new battery of lenses-the finest that at that time had ever been put into the hands of man-I was enabled to show in succession that each motile form of Bacterium up to $B$. lineola accomplished its movements by fibres or flagella; and that in the act of self-division, constantly taking place, a new fibre was drawn out for each half before separation.

(To be continued.)

\section{THE PERIPATETIC METHOD OF INSTRUC-} TION IN SCIE NCE AND ITS DEVELOPMENT

$T \mathrm{HE}$ object of this paper is to plead for the introduction of science as a part of the system of ordinary education in all public elementary schools, and to describe the method by which alone, in the opinion of the writer, it is possible that this should be accomplished. 'There is a general consensus of opinion that a far larger place than has hitherto been allowed in England should be assigned to science in our national system of education, as well as in our grammar-schools and Universities; but no strong conviction yet exists that a certain amount of strict and definite scientific training should be given to all the scholars in our public elementary schools as soon as they are prepared to receive it, which is practically found to be after they have passed the fourth standard. The extent of this claim for the introduction of science as a part of the ordinary curriculum of a public elementary school must be noted, in order that the worth and importance of the proposed method for securing thoroughly effective teaching may be understood.

The provision of special scholarships for those who possess exceptional intellectual power-admirable and necessary as this is--does not meet the broad claim I make. To furnish stages in the ladder by which a lad of mark, endowed with " five talents," may climb from the elementary school to the science college, is only to offer to the children of the poor opportunities to which they are justly entitled by virtue of the fact that genius, like truth, can neither be bought or sold, and is bestowed upon men entirely apart from any considerations connected with social rank and circumstances. But scholars of average ability, those who have no special endowments qualifying them for exceptional careers, ought not to be kept in ignorance of the fixed laws and the majestic marvels of the world in which they will have to labour, or to be deprived of the practical guidance, the intellectual interests, and the protection against coarse and degrading tastes, which scientific training is capable of bestowing upon

${ }^{I}$ Paper read at the Social Science Congress, September 22, by Henry W. Crosskey, LL.D., Chairman of the School Managcment Committee of the Birmingham School Baard. 
their lives. Only a few can rise to eminence ; and it is an unmitigated misfortune for any lad to be encouraged to trust to his intellectual powers for his daily bread, unless he has a fair chance of becoming eminent ; but all may possess the scientific knowledge which will give dignity to their daily toil ; and the workshop itself may be ennobled.

Neither does the establishment of higher-grade Board schools, in which scientific instruction is given, meet the necessities of the case. The vexed and complicated questions involved in the general organisation of the very miscellaneous collection of schools now existing in England do not fall within the scope of this paper; but I find that many members of School Boards believe that all that is required for scientific instruction will be done when higher grade Board schools are opened; and, by means of examinations and scholarships, admission is brought within reach of a certain number of poor children unable to pay the fee.

Now, the grading of schools must educationally depend upon the time which the scholars can be expected to devote to education; and each grade of schools ought to have a curriculum, determined in its extent and balanced in its parts, according to the number of years which can be spent upon it. The public elementary school should furnish the completest possible education for those who can remain at school until the age of fourteen or fifteen ; the higher-grade schools, which properly belong to the secondary system, should be adapted to the wants of scholars who can be retained a year or two longer. The higher-grade school cannot therefore supply the place of the public elementary school to the poor man, who is obliged to send his children to work at a comparatively early ase ; the number of subjects taught, and the relative number of hours given to them, will not be balanced in a way to suit his requirements.

My contention is that science ought not to be omitted from the educational training of the poorest of our people. The daily concern of the lives of the poor is with forces and materials upon which science throws the strongest light. Their work is bound up with scientific laws. Want of knowledge often means bad work or want of work ; and even the spread of pestilence, disease, and death.

The establishment of higher-grade Board schools ought not, therefore, under any circumstances, to be permitted to lower the standard of education in public elementary schools. I speak emphatically on this point, because I believe that the working men of this country will need to take the most watchful heed lest they should be deprived of the education all their children are capable of receiving by the relegation of scientific subjects to schools placed beyond their reach by high fees, mitigated by only a small proportion of free scholarships.

Weither will the opening of technical schools suffice for the scientific instruction of our people. Technical schools cannot do their proper work if their students have had no preliminary training, and are unfamiliar with at least the elementary principles of physics. Lads who have grown into young men without being carried through any systematic and experimental course of scientific instruction will find it almost impossible, after they have leift school, to prepare themselves properly for taking advantage of technical colleges, especially when, as among the working classes, their evenings only are at their own disposal.

In order that science may be effectively taught in public elementary schools, the following conditions must be observed :--

I. It must be taught experimentally. - Actual demonstration must accompany the lessons at every stagc. At no point at which an experiment is possible must it be omitted. The minds of young lads of the type of those attending public elementary schools will be opened and enlarged by experimental demonstrations, but they will not be reached in any other way. Scholars may be able to pas examinations by getting up textbooks; but unless they are made experimentally familiar with the principles of the science they are studying, their knowledge will hang as a dead weight upon their minds, impeding rather than quickening their intellectual activity. Those who have witnessed, as I have often done, the effect of an experimental lesson in science upon large classes of children, often drawn from the poorest of the poor, will not think this insistence upon a plenitude of experiments cxa gerated. The demonstration thoroughly awakens their minds; their eyes glisten; there is a long-drawn " $\mathrm{Ha}$ " when the result accords with the theory which the teacher has expounded; and que.tions will soon show that they are not merely wondering at a conjuring trick, but that a new world, hidden within the world of machinery with which they are familiar through the daily avocations of their parents, is being revealed to them.

2. Science must not only be taught experimentally, but systematically and continuously. The "getting up" of some branch of science during three or four months as a "specific subject" for examination is of little use. "Passes" may be won; but no scientific training will be given.

From these considerations it directly follows that special science demonstrators must be appointed if our scholars are to receive a scientific training of any worth. It may be asked, cannot the work be done by one of the ordinary masters of the school? I am bound to reply that in my opinion-an opinion not lightly formed, but based on observations extending over a not inconsiderable area-it is absolutcly impossible to obtain any training which can be called scientific, and prove of practical value, for the scholars of our public elementary schools, without the appointment of special science demonstrators.

In the first place, no man can be a good science demonstrator who does not devote to the work the greater part of his daily life. To perform experiments well is as much an art to be acquired by continuous study and practice as playing the piano. Fertility of resource, quickness of eye and hand, steadiness of mind, keenness of observation, are qualities essential to the demonstrator, which cannot be acquired without culture or retained without constant employment. The master of a school has many subjects to teach and many duties to discharge. $\mathrm{He}$ cannot, by any possibility, give any sufficient proportion of his time to the art and practice of scientific demonstration.

It may be said that an expert cannot be required for scholars of the age of those attending public elementary schools, and that any experiments they can understand can be easily performed by any ordinary teacher. Those who have studied any branch of physical science, however, will, I think, agree with me that no science can be well taught except by a man who has had a special scientific training; and that the simplest experiments are best performed and made the most intelligible by those capable of carrying on the more recondite and difficult investigations.

It is a great mistake to imagine that it is a light and easy matter to experiment before a class of scholars, such as those found in our Board schools. They are on the alert for any mistake; they are ready to raise the most curious and subtle doubts, and to ask the most perplexing questions. The only man capable of dealing with such a class of scholars is a man they are compelled to recognise as a master of the science he is. teaching.

In the second place, even if the head master of a public elementary school were a scientific expert and managed to keep abreast with the advance of the scientific knowledge of his day, he would find it completely out of his power to act as a science demonstrator and to conduct the general work of his school. The preparation necessary for giving a good science lesson cannot be made without a larger expenditure of time than the proper management of his school will leave at his disposal. The mechanical arrangements for experiments often demand longcontinued and anxious watchfulness and care. Every experiment ought to be tried over, before it is performed in the class, to. avoid the risk of failure. The proper selection of experiments, as well as their performance, is in itself an art.

For the teaching of science in public elementary schools, therefore, these things are necessary: (I) sufficient apparatus, and of course a laboratory in which experiments can be prepared; and (2) a staff of special sciencc demonstrators.

The expense of providing apparatus, building a laboratory, and supporting a science demonstrator at every single school in town and country, would be as enormous as unnecessary. By the general adoption, however, of what is known as the "peripatetic" method of instruction, all difficulties can be solved; and science can be effectively taught in every public elementary school. I do not think, indeed, that any other satisfactory method an elementary schools can be reached and the services of those trained scientific men, whose teaching of the elementary principles of science is alone to be relied upon, he secured for the great mass of our people. The peripatetic method has been adopted in liverpool and Birmingham, and as I can testify so far as Birmingham is concerned, the results have been as satisfactory as remarkable.

The chief characteristics of this method are extrewely simple :- 
I. As regards "plant," it involves (I) the building of a laboratory in some central position; (2) the purchase of a stock of apparatus; (3) the provision of a small hand-cart by which boxes containing apparatus can be readily carried from school to school.

II. A special science demonstrator is appointed, with such assistants as the number of schools to be dealt with may require.

III. The duties of the science demonstrator are (I) to prepare a scheme of lessons and arrange the experiments for their illustration: in Birmingham, in the boys' departments, mechanics is taken as a "specific subject," and in some schools magnetism and electricity are added; in the girls' departments, domestic economy is taken, and anirual physiology is in some cases added; (2) to visit the schools in succession, and give at each school a lesson profusely illustrated by experiments, the re. quisite apparatus being brought by the hand-cart from the central laboratory.

IV. The regular staff of the school assists the demonstrator, and is assisted by him in the following ways :-

(I) A teacher on the staff of the school is present at every demonstration, and is thus prepared to enforce and continue its lessons in the intervals elapsing between the demonstrator's visits.

(2) The scholars have opportunity given them during school hours to write answers to questions set by the dem mnstrator, who eximines their papers.

In Birmingham a "demonstration" is given in each department once a fortnight. It would be, however, a great improvement if the demonstrator or one of his staff could visit each school once during every week. The science staff consists of a chief demonstrator (Mr. W. Jerome Harrison, F.G.S., whose services deserve the warmest acknowledgment), three assistan demonstrators, who assist in giving lessons at the schools, and a junior laboratory assistant. Two youths are employed to work the hand-cart. The whole a mount of salary paid to this staff amounts to $750 \%$ per annum.

Scientific instruction is given by this method in thirty boys' schosls and thirty girls' schools, containing about 32,000 scholars, the numbers in the classes and the specific subjects taken being :-

$$
\begin{array}{lcccccc}
\text { Mechanics ... } \ldots & \ldots & . . & \ldots & \ldots & \ldots & 2400 \text { Boys } \\
\text { Magnetism and Electricity } & \ldots & \ldots & \ldots & 300 \\
\text { Domestic Economy } & \ldots & \ldots & \ldots & \ldots & \ldots & \mathbf{1} 800 \text { Girls } \\
\text { Animal Physiology } & \ldots & \ldots & \ldots & \ldots & \ldots & 100
\end{array}
$$

Objections may possibly be taken to this system in the following directions :-

I. Its cost.- It being granted, however, that thorough and systematic scientific instruction ought to be introduced into elementary schools, the peripatetic metbod is the very cheapest that can be devised. One set of apparatus serves for many schools, and one laboratory suffices for the preparation of the experinents. The services of the staff are utilised to the utmost ; and the amount of salary to be charged against each school is trifling. Supposing twenty schools in a town or neighbouring villages to be grouped together, the system might be worked at a very slight expense to each. The investment of capital required would be less than 1000 l., viz. :-

Building of Central Laboratory ${ }^{1} \quad \ldots \quad \ldots \quad \ldots \quad f_{6700}$

\begin{tabular}{rrrrrrrrrr} 
Apparatus & $\ldots$ & $\ldots$ & $\ldots$ & $\ldots$ & $\ldots$ & $\ldots$ & $\ldots$ & $\ldots$ & \\
\hline
\end{tabular}

$\frac{300}{61000}$

The annual working expenses would be--

Salaries of science demonstrator and assistant ... $£_{400}$

Waste of chemicals, renewal of apparatus, \&c...

Expense of moving apparatus from laboratory to school ...

Ample provision could be made at this cost for twenty schools, each having accommodation for 300 or 400 children, i.e. each of the associated schools could obtain, for about 25 l. a year, thoroughly good experimental instruction for all scholars who have passed the fourth standlard.

II. It may be asked whether, in the short time that can be allowed for any specific subject, it is possible to obtain results of sufficient educational worth to justify the expenditure of labour, thought, and money I am advocating. As a reply to

${ }^{1}$ The Birmingham laboratory cost (with fittings) 1450l., but it has a lecture-room and private room for demonstrator attached. this objection, I can point without fear to the results actually attained in Birmingham; an hour to an hour and a half a week being all the time which has been spared for science, including the fortnightly demonstration, the recapitulation, and preparation of exercises. The teaching being experimental, an impresis made upon the minds of the scholars which can neither be equalled or measured by the effects of ordinary class teaching, lecturing, or book work. The scholars are induced to think, and read, and prepare models of machines and drawings out of school hours; and during school hours they are found to apply themselves with a will to their scientific exercises. Prof. Poynting (of Mason College) has examined a large number of boys competing for a scholarship, and reported to the Board that "the boys showed that they had seen and understood the experiments which they described, that they had been taught to reason for themselves upon them, and that they were not nerely using forms of words which they had learned without attaching physical ideas to them." Specimens of the models made by the children, their drawings, a d examination papers, have been exhibited at the International Health Exhibition, of which the subjoined account is given in the School Board Chronicle (August 9, 1884) :- "The cabinet of machines and models and copies of the science apparatus used by the demonstrators in their experiments is well worthy of a visit. It shows the extent and nature of the interest which the children take in this practical form of education. Most of the models have been made by the children at their homes, and often with very inferior tools. One lad has a copy of the Chinese windlass, another makes a little pile engine, and a third illustrates the inclined plane, a fourth the mariner's compass, and so on through a great variety of objects, until a very tolerable little collection of rough but serviceable apparatus has been brought. In cases extending the length of one of the walls of the room is a collection of specimen papers and drawings, prepared at the demonstrator's fortnightly examination of the results of his preceding lesson, and no further justification of the system than these papers can be needed. ${ }^{\prime \prime}$

In comparing these models and papers with others, it must be remembered that the Birmingham work was not done in any "higher-grade" institutions, with high fees and picked scholars, but indicates the kind of scientific Iraining that may be given by the help of the peripatetic method in any public elementary school.

III. Great anxiety is felt by many lest the introduction of science into elementary schools should result in mere "cram"; and a number of hard technical words be repeated by rote to be forgotten as soon as school is left. It is not unusual to hear a laugh raised by the quotation of some technical word from an examination paper, as though its use reduced the system to an absurdity. Scientific facts are, however, most clearly expressed in scientific language. Even young scholars gain by knowing the right words by which physical facts and laws are described; and their intellects are bemuddled by vague expressions. The employment of scientific words is no proof of "cram." I admit, as a matter of course, that the attempt to teach science without demonstrating cxperimentally every fact and law, must result in cramming of the worst description; but experimental teaching gives the death-blow to cram.

IV. Will not, however, it is sometimes asked, the introduction of this system of scientific teaching interfere with the progress of the children in writing, reading, and arithmetic? Will nit the elements of ordinary education be neglected because of the attention demanded for such scientific subjects as mechanics, magnetism, and electricity? On the contrary, it is found as a matter of fact, that the intellectual life of the school is quickened in every direction by the study of science. The scholars find that the "three R's" are not dull, dry, and abstract pursuits, but keys to a world of new marvels and interests. The schools under the Birmingham Board in which there is the keenest interest in science are certain to prove the schools in which the ordinary work is best done. Since 1880 , when the science de-

\begin{tabular}{|c|c|c|c|c|c|c|c|}
\hline \multicolumn{4}{|l|}{ Year } & \multicolumn{2}{|c|}{$\begin{array}{l}\text { Number of passes in } \\
\text { specific subjects }\end{array}$} & \multicolumn{2}{|c|}{$\begin{array}{l}\text { Percentage of passes } \\
\text { in the "three } \mathrm{R}^{\prime} \mathrm{s} \text { " }\end{array}$} \\
\hline 1880 & $\ldots$ & & & .. 84 I &.. & $\ldots$ & 847 \\
\hline 8 & $\ldots \quad \ldots$ & $\ldots$ & $\ldots$ & ... 1724 & $\ldots$ & $\ldots$ & 88.4 \\
\hline 188 & & & $\ldots$ & ‥ 3114 & $\ldots$ & $\ldots$ & $92 \cdot 6$ \\
\hline 1883 & $\left\{\begin{array}{r}\text { New } \\
\text { higher }\end{array}\right.$ & & & 3150 & $\cdots$ & $\cdots$ & $89 \cdot 6$ \\
\hline
\end{tabular}
monstrator was first appointed, the percentage of passes in the "three R's" has steadily increased, as well as the number of passes in specific subjects. 
Various causes have, no doubt, contributed to this result; but the proof is positive that the introduction of science has not interfered, to say the least, with elementary education in the "three R's."

$V$. On the first introduction of the system there may be a certain amount of antagonistic feeling aroused amongst some head masters and mistresses. In Birmingham this was indeed to some small extent the case. Some head teachers feared that the demonstrator would prove a new inspector, who, having to discharge duties as a teacher, might unduly interfere with their own functions, and that some conflict of authority might occur. To the best of my knowledge, however, this feeling has entirely disappeared. The only complaints which I hear as Chairman of the School Management Committee, are when the experimental lessons are omitted at any school through any stress of examination work or accidental circumstance. The masters find that the science demonstrators render them valuable assistance and do a work which it is out of their own power to accomplish.

In order to apply the severest test to the peripatetic system, I applied to the head master of a large school, situated in one of the very poorest districts in Birmingham, and attended by children whose social surroundings are, as a rule, almost as unfavourable to intellectual development as they can possibly be. The school has accommodation for 416 boys, and an average attendance of about 350, 4I 4 being sometimes present during the week.

The reply of the head master to my request that he would inform me of the results of the science teaching in his school, lifts the whole question out of the region of controversy.

\section{Dartmouth Street Boys' Board School,}

Birmingtham, September 9, 1884 .

Rev. Sir,--In reply to yours of this morning, I beg to make the following remarks :--

The results from the science lessons given in this school are very gratifying. I have seen results in a variety of ways both in and out of school.

The interest taken in these lessons, both by parents and boys, is surprising. Many a mother has, to my frequent knowledge, inconvenienced herself in her domestic duties on certain days when we have sent word for her boy to be present, as the science demonstrator was expected that morning. The day is well remembered by most of them, and eagerly looked forward to. The attendance in the uppermost class is wonderfully increased on the mornings these lessons are given.

The results in other subjects in those standards where science is taught are none the less satisfactory. A greater intelligence and thought are quickly discovered when we are dealing with the other subjects.

Teachers are more encouraged when brighter matcrial to work with is placed in their hands.

Other important subjects have impressed me very much, viz. the desire of the boys after leaving school to continue to study some science subject at some of our science classes.

Older brothers, too, have been induced to go to science classes through seeing the growth of knowledge in those much younger than themselves.

Many persons who have reason to come in contact with the boys after leaving school, have expressed themselves in tones of great regret that such instruction was not given when they attended school.

I remain, Rev. Sir, Your obedient servant

\section{Rev. Dr. Crosskey.}

T. H. Purceit.

As a development of the systematic and experimental system of science training I have described - a system only rendered possible of adoption by the employment of the peripatetic method-a new kind of Board school has been opened in Birmingham, for the purpose of enabling the scientific work com. menced in the elementary school to be continued by the more advanced scholars before they enter upon their respective employments in workshops and factories.

The arrangements of the peripatetic system will suffice until the sixth standard is passed ; but special provision must be made for those lads who can remain a year or two longer at school, and whose future employments render the extension of their scientific training desirable. A large proportion of those who pass the sixth standard are obliged to earn their livings at once ; for these various evening classes are available. But a certain number of working men can, by an effort, manage to exempt their children from toil, say for an extra two years.
The question therefore arises whether special provision cannot be made for scholars who must ultimately earn their living as working men, but whose parents can afford to keep them at school for two years after they have passed the sixth standard?

It is evident that for such scholars increased facilities for scientific study will have a peculiar, indeed almost an incalculable, importance.

They have been well grounded in the first principles of science and familiarised with the management of apparatus and the conduct of experiments during their school career. Their work in life will be largely increased, not only in pecuniary and mechanical, but in intcllectual and moral value, by scientific knowledge.

To meet the wants of this class, a school has been opened as an experiment, in New Bridge Street, Birmingham, in premises belonging to the Chairman of the Board (Mr. George Dixon), who, at the cost of more than 2000l., has adapted them for the purpose, and placed them rent free at the service of the Board.

The characteristics of this school are the following :-

I. It is especially intended for scholars who will have to become working men, but whose parents can keep them at school after they have passed the sixth standard," and the fee $(3 d$. a week) is adapted to their means.

II. While a seventh standard school under the Code, the instruction given is largely scientific and technical; and a special staff of trained scientific men has been appointed. There is a special master for chemistry and metallurgy; another master for mechanics and physics; a drawing master ; and a mathematical master; a highly qualified scientific man being placed at the head. Workshop instruction is provided, and includes a knowledge of the chief wood tools, and the properties of materials, while it supplements the mechanical drawing of the schoolroom, and is an aid to the study of theoretical mechanics.

III. The course of instruction is arranged to extend over two years. In the first year the scholars take ordinary standard work, together with mathematics, mechanics, drawing, chemistry, and workshop practice.

In the second year the study of mathematics will be continued, but it is intended that the scholars shall then specialise their studies in one of the following groups: (1) Chemistry and Metallurgy. (2) Mechanics and Machine Drawing. (3) Physics and Geometry.

The peculiarity of this scheme is that it is not an attempt to benefit a few picked scholars or to provide a higher-grade school for those able to pay high fees, but that it is a continuation of the science training given by means of the peripatetic method in every ordinary elementary school under the Board.

It has already been made evident that a large capacity for scientific investigation-amounting, I believe, almost to a special genius for the study of science-exists among our English people, which has never yet received its full and fair development. The country is undoubtedly awakening to the necessity of making better provision for the study of science, in order that our manufacturers may hold their own in the markets of the world. Other and higher blessings will follow in its train. Labour, in being made intelligent, will cease to be so loveless as it often is, and the lives of toiling thousands will be filled with larger interests, guided by finer tastes, and enriched with nobler joys.

\section{THE ASSOCIATION OF GERMAN NATU- RALISTS AND PHYSICIANS}

THE annual gathering of this influential Society was held this year at Magdebury during the week ending September 23 , simultaneously with the yearly meetings of the German Botanical and Meteorological Associations. The proceedings were opened by the President, Dr. Gaehde, whose address was followed with a few appropriate remarks by Prof. Hochheim on the services rendered to science by Guericke and other distinguished physicists.

The formal work of the meeting was opened with a paper by Prof. Rosenbach of Göttingen, on the microscopic organisms present in festering wounds. After a brief reference to the discoveries of Koch and Ogston, the author dwelt upon his own investigations, by which he claims to have proved that all purulent matter is primarily due to minute animal organisms. The 